\title{
PERFORMA DAN ANALISIS KONSUMSI ENERGI PENGERINGAN RUMPUT LAUT MENGGUNAKAN ENERGI GELOMBANG MIKRO
}

\section{Performance and Energy Consumption Analysis of Seaweed Drying using Microwave}

\author{
Arif Rahman Hakim*, Wahyu Tri Handoyo, dan Adrianto Widi Prasetyo \\ Loka Riset Mekanisasi Pengolahan Hasil Perikanan JI. Imogiri Barat Km. 11,5, Yogyakarta, Indonesia \\ *Korespondensi Penulis: arifrahmanh11@gmail.com
}

Diterima: 13 Desember 2019 ; Direvisi: 19 April 2020 ; Disetujui: 6 Mei 2020

\begin{abstract}
ABSTRAK
Pengeringan menggunakan energi gelombang mikro menjadi alternatif agar pengeringan berjalan lebih cepat tanpa terpengaruh kondisi cuaca. Namun performa dan efisiensi energi dalam mengeringkan rumput laut belum diketahui. Tujuan penelitian ini adalah untuk mengetahui performansi pengeringan rumput laut menggunakan energi gelombang mikro (microwave) dan analisa konsumsi energinya. Metode yang digunakan ialah mengeringkan rumput laut segar dalam oven gelombang mikro secara batch. Dalam proses pengeringan dilakukan variasi level daya $(400,500,600$ watt) ke dalam oven gelombang mikro dan variasi ketebalan rumput laut $(3$, $5,7 \mathrm{~cm}$ ). Parameter yang diamati meliputi rasio kadar air (moisture ratio/MR), laju pengeringan $(\mathrm{g} /$ menit), difusi efektif air $/ D_{\text {eff }}\left(\mathrm{mm}^{2} /\right.$ detik), specific energy consumption $/ S E C\left(\mathrm{~J} / \mathrm{g} \mathrm{H}_{2} \mathrm{O}\right)$ dan efisiensi energi (\%). Hasil penelitian menunjukkan, level daya magnetron 600 watt menghasilkan $M R$ terendah $(0,19)$, laju pengeringan tertinggi $(13,15 \mathrm{~g} /$ menit $)$ dan $D_{\text {eff }}$ tertinggi $\left(2,28 \times 10^{-2} \mathrm{~mm}^{2} /\right.$ detik). Rumput laut ketebalan $3 \mathrm{~cm}$ memperoleh $M R$ terendah $(0,05)$, laju pengeringan tertinggi $(6,42 \mathrm{~g} / \mathrm{menit})$ dan $D_{\text {eff }}$ tertinggi $\left(9,42 \times 10^{-2} \mathrm{~mm}^{2} /\right.$ detik). SEC pengeringan sebesar 4,38-4,51 J/g $\mathrm{H}_{2} \mathrm{O}$ dan efisiensi energi $22,56-23,42 \%$ untuk level daya 400-600 watt. Perbedaaan level daya tidak memberikan pengaruh signifikan terhadap SEC dan efisiensi. Sedangkan variasi ketebalan rumput laut antara $3 \mathrm{~cm}$ dan $7 \mathrm{~cm}$ memberi hasil yang berbeda. SEC terendah diperoleh pada perlakuan rumput laut tebal $3 \mathrm{~cm}$ yaitu $2,96 \mathrm{~J} / \mathrm{g} \mathrm{H}_{2} \mathrm{O}$ sementara efisiensi tertinggi pada rumput laut dengan tebal $5 \mathrm{~cm}$ yaitu 22,93\%. Oleh karena itu pengeringan rumput laut menggunakan energi gelombang mikro dengan level daya 600 watt dan ketebalan $3 \mathrm{~cm}$ menghasilkan performasi dan konsumsi energi yang lebih baik.
\end{abstract}

KATA KUNCl: rumput laut, pengeringan, energi gelombang mikro

\begin{abstract}
Microwave drying becomes alternative method to get faster process without being influenced by weather. However performance and energy efficiency of microwave drying for seaweed are still unknown. This research aims to find out performance of seaweed drying in microwave oven as well as energy consumption analysis. The method used was drying seaweed in microwave oven. Seaweed drying was conducted at various power level (400, 500, 600 watt) and thickness of seaweed $(3,5,7 \mathrm{~cm})$. Observed parameters were moisture ratio/MR, drying rates $(\mathrm{g} / \mathrm{min})$, effective diffusion/ $D_{\text {eff }}\left(\mathrm{mm}^{2} / \mathrm{s}\right)$, specific energy consumption/SEC $\left(\mathrm{J} / \mathrm{g} \mathrm{H} \mathrm{H}_{2} \mathrm{O}\right)$ and energy efficiency $(\%)$. Result of research showed that power level, 600 watt of magnetron produced lowest MR $(0,19)$, highest drying rate and $D_{\text {eff }}$ i.e $13.15 \mathrm{~g} / \mathrm{min}$ and $2.28 \times 10^{-2} \mathrm{~mm}^{2} / \mathrm{s}$ respectively. Seaweed $3 \mathrm{~cm}$ thickness achieved lowest MR (0.05), highest drying rates $6.42 \mathrm{~g} / \mathrm{min}$ and $D_{\text {eff }} 9.42 \times 10^{-2} \mathrm{~mm}^{2} / \mathrm{s}$. SEC of drying were 4.38-4.51 J/g $\mathrm{H}_{2} \mathrm{O}$ while energy efficiency were $22.56-23.42 \%$ for $400-600$ watt. Differences of power level have not given significant effect to SEC and efficiency values. Whereas differences of seaweed thickness between $3 \mathrm{~cm}$ and $7 \mathrm{~cm}$ have given significant effect. Seaweed in $3 \mathrm{~cm}$ thickness resulted in the lowest SEC i.e $2.96 \mathrm{~J} / \mathrm{g} \mathrm{H} \mathrm{H}_{2} \mathrm{O}$, however, the highest efficiency energy was $5 \mathrm{~cm}$ thickness i.e 22.93\%. Therefore drying seaweed utilize microwave energy of 600 watt power level and $3 \mathrm{~cm}$ thickness generated better performance and energy consumption.
\end{abstract}

KEYWORDS: seaweed, drying, microwave energy 


\section{PENDAHULUAN}

Rumput laut merupakan komoditas terbesar perikanan budidaya di Indonesia, tercatat 10,78 juta ton dihasilkan pada tahun 2017 (KKP, 2018). Rumput laut banyak dimanfaatkan dalam berbagai macam campuran bahan pangan baik sebagai pengental maupun emulsifier hingga untuk bahan baku kosmetik dan farmasi. Proses awal pengolahan rumput laut adalah pengeringan, hal ini bertujuan untuk memperpanjang masa simpan dan mempermudah transportasi.

Pengeringan rumput laut dilakukan menggunakan pengeringan konvensional yaitu dijemur di bawah sinar matahari secara langsung dan beberapa menggunakan alat pengering sistem konveksi dan konduksi. Meskipun murah dan mudah, metode tersebut akan sangat tergantung cuaca, pada musim penghujan proses pengeringan akan berjalan lebih lama sekitar 3-4 hari bahkan lebih. Lebih lanjut, alat pengering konveksi dan konduksi memiliki kelemahan efektifitasnya yang rendah sehingga waktu pengeringan juga lama dan energi yang digunakan banyak terbuang.

Fudholi, Sopian, Othman dan Ruslan (2014) melakukan penelitian pengeringan rumput laut merah menggunakan pengering tenaga surya dan pemanas (solar dryer), dibutuhkan waktu 2 hari proses pengeringan untuk menghasilkan rumput laut dengan kadar air sebesar $10 \%$. Nilai SEC dilaporkan sebesar $2,62 \mathrm{kWh} / \mathrm{kg}$ atau sekitar $9432 \mathrm{~J} / \mathrm{g}$ dengan suhu ruang antara $35-60^{\circ} \mathrm{C}$. Sedangkan penelitian Suherman et al. (2018) tentang karakteristik perbedaan metode pengeringan rumput laut, menyebutkan bahwa untuk mencapai kadar air 12,2\% dibutuhkan energi 1493 $\mathrm{kJ} / \mathrm{kg}$ menggunakan solar dryer, $1338 \mathrm{~kJ} / \mathrm{kg}$ dijemur sinar matahari dan $1620 \mathrm{~kJ} / \mathrm{kg}$ ketika menggunakan oven listrik.

Gelombang mikro adalah gelombang elektromagnetik dengan frekuensi $300 \mathrm{MHz}-300 \mathrm{GHz}$ (Fu, Chen, \& Song, 2017; Metaxas \& Meredith, 2008). Pada pengeringan menggunakan gelombang mikro terjadi pemanasan dielektrik yaitu energi gelombang mikro dikonversi dalam bahan secara langsung menjadi energi panas melalui friksi antar molekul. Hal ini memberikan beberapa kelebihan di antaranya terjadi pemanasan tanpa sentuhan, pemanasan volumetrik, pengeringan selektif dan pemanasan cepat (Zhao et al., 2019).

Pengeringan dengan gelombang mikro disebut pengeringan selektif karena energi gelombang mikro akan mudah diserap oleh material yang mengandung nilai dielectric tinggi seperti air. Oleh karena itu gelombang mikro akan bekerja optimal jika bahan yang dikeringkan mengandung kadar air yang tinggi. Sementara itu, gelombang mikro juga bersifat volumetrik yaitu proses kenaikan suhu akan terjadi pada bagian dalam material terlebih dahulu kemudian panas merambat ke permukaan bahan. Berbeda dengan pengeringan konvensional, panas akan terjadi pada permukaan bahan kemudian merambat ke dalam bahan sehingga seringkali air dalam bahan sulit keluar. Keunikan ini yang menyebabkan proses pengeringan dalam gelombang mikro berjalan lebih cepat (Song et al., 2016).

Rumput laut jenis Eucheuma cottoniiadalah bahan baku karaginan oleh karena itu pengaruh proses pengeringan diharapkan tidak merusak sifat fungsionalnya saat diproduksi menjadi karaginan. Menurut Wahyu, Prasetyo, dan Hakim (2019) sifat karaginan (kekuatan gel dan sulfat) yang dihasilkan dari rumput laut Eucheuma cottonii yang dikeringkan dengan oven gelombang mikro tidak menunjukkan penurunan sifat dibandingkan rumput laut hasil pengeringan dengan sinar matahari.

Dengan karakteristik pengeringan menggunakan gelombang mikro tersebut, telah banyak dikembangkan teknologi pengeringan berbasis gelombang mikro pada berbagai bidang seperti pada industri pengolahan pangan, industri biologi, industri pertanian serta pengolahan mineral. Rumput laut sendiri memiliki kandungan dominan berupa air sehingga mempunyai kemampuan untuk menyerap energi gelombang mikro yang tinggi. Namun demikian masih sangat sedikit informasi pemanfaatan gelombang mikro untuk pengeringan rumput laut. Oleh karena itu, penelitian ini bertujuan untuk mengetahui performansi pengeringan rumput laut menggunakan gelombang mikro serta besaran konsumsi energi dalam proses pengeringannya.

\section{BAHAN DAN METODE}

\section{Bahan}

Rumput laut segar jenis Eucheuma cottonii (Gambar 1) diperoleh dari pembudidaya di Kabupaten Sumenep Jawa Timur. Dalam perjalanan menuju Laboratorium rumput laut dimasukkan dalam kontainer berinsulasi dan tambahkan es hingga suhu bisa dipertahankan pada $5-10{ }^{\circ} \mathrm{C}$. Sebelum proses pengeringan rumput laut diletakkan dalam ruangan terbuka agar suhu rumput laut mencapai suhu ruang. Karakteristik rumput laut yang digunakan antara lain rata-rata kadar air $86,52 \%$, densitas $1,072 \mathrm{~g} / \mathrm{cm}^{3}$, panas spesifik $500,08 \mathrm{kal} / \mathrm{g}$ dan kesetimbangan kadar air $28,78 \%$. 


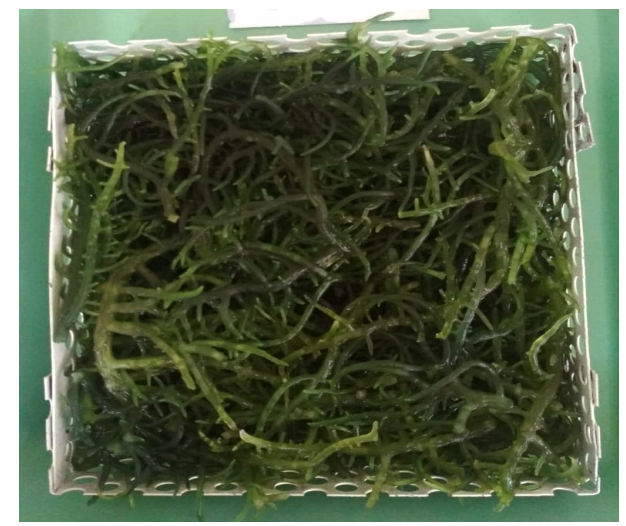

Gambar 1. Rumput laut E. cottonii segar sebagai bahan baku proses pengeringan

Figure 1. Fresh E. cottonii as raw material of drying

\section{Alat}

Pengeringan rumput laut menggunakan microwave oven komersial Panasonic NN-GD692S 1000 watt, dimensi cavity $350 \times 350 \times 290 \mathrm{~mm}(\mathrm{P} \times \mathrm{L} \times \mathrm{T})$ dengan $340 \mathrm{~mm}$ turntable plate, frekuensi gelombang 2,45 $\mathrm{GHz}$. Pada saat pengeringan dipilih mode microwave sehingga yang bekerja hanya gelombang mikro tanpa mengaktifkan mode pemasakan lainnya (grill). Perubahan berat rumput laut dilakukan menggunakan Timbangan digital Fortuno WSP kapasitas $3 \mathrm{~kg}$ deviasi $0,1 \mathrm{~g}$. Suhu permukaan diukur menggunakan infrared termometer Sanfix WT550.

\section{Metode}

Rumput laut sebanyak $1000 \mathrm{~g}$ dipotong-potong dengan ukuran bervariasi $5-10 \mathrm{~cm}$, untuk memudahkan peletakan dalam wadah, lalu dimasukkan dalam oven gelombang mikro dengan pengaturan daya berbeda yaitu P4 (400 watt), P5 (500 watt) dan P6 (600 watt). Pada perlakuan ini waktu pengeringan selama 60 menit dengan ketebalan sampel rumput laut $5 \mathrm{~cm}$.
Daya gelombang miko yang menghasilkan penurunan berat paling tinggi selanjutnya digunakan untuk uji pengeringan dengan variasi ketebalan rumput laut yang berbeda $(3 \mathrm{~cm}, 5 \mathrm{~cm}, 7 \mathrm{~cm})$. Pada perlakuan perbedaan ketebalan, berat rumput laut sebanyak 350 g dan waktu pengeringan selama 30 menit. Untuk mendapatkan ketebalan tersebut dengan berat sampel yang sama dibuat wadah dengan dimensi berbeda. Wadah I dimensi: $22 \times 22 \times 3 \mathrm{~cm}^{3}$; wadah II : $17 \times 17$ $\times 5 \mathrm{~cm}^{3}$; wadah III : $14,5 \times 14,5 \times 7 \mathrm{~cm}^{3}$, wadah tersebut berbahan dasar besi perforated kemudian dilapisi cat (Gambar 2). Sedangkan perubahan berat dimaksudkan untuk mengakomodir perubahan dimensi wadah sampel agar perbedaan ketebalan bisa diterapkan.

Parameter yang diukur ialah perubahan berat rumput laut (g) dan suhu permukaan rumput laut $\left({ }^{\circ} \mathrm{C}\right)$. Pengukuran dilakukan setiap 10 menit. Pengukuran dari parameter yang dianalisis meliputi rasio kadar air (MR), specific energy consumption (SEC) $\left(\mathrm{J} / \mathrm{g} \mathrm{H}_{2} \mathrm{O}\right)$, efisiensi energi (\%), difusi kadar air ( $\mathrm{mm}^{2} /$ detik) dan

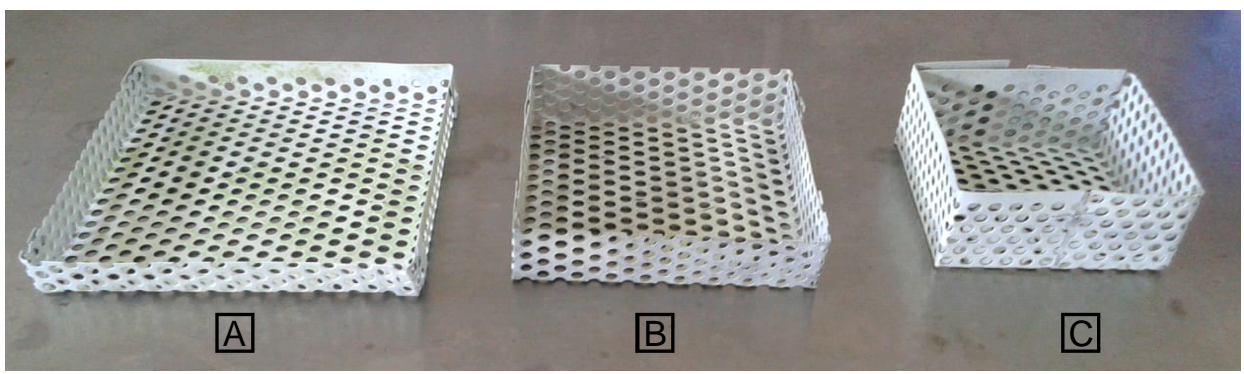

Keterangan/Notes:

$\mathrm{A}=$ dimensi $22 \times 22 \times 3 \mathrm{~cm}^{3} /$ Dimension of $22 \times 22 \times 3 \mathrm{~cm}^{3}$

$\mathrm{B}=$ dimensi $17 \times 17 \times 5 \mathrm{~cm}^{3} /$ Dimension of $17 \times 17 \times 5 \mathrm{~cm}^{3}$

$C=$ dimensi $14,5 \times 14,5 \times 7 \mathrm{~cm}^{3} /$ Dimension of $14,5 \times 14,5 \times 7 \mathrm{~cm}^{3}$

Gambar 2. Wadah rumput laut untuk proses pengeringan

Figure 2. Seaweed container for drying 
laju pengeringan ( $g /$ menit). Semua perlakuan pada penelitian ini dilakukan sebanyak 4 kali ulangan.

\section{Rasio kadar air (moisture ratio/MR)}

Kadar air bahan saat pengeringan per waktu dapat ditransformasi sebagai moisture ratio $(M R)$ yang dihitung menurut Manikantun, Barnwalr, \& Goyal, (2014), menggunakan persamaan (1).

$M R=\frac{\mathrm{MC}_{\mathrm{t}}-\mathrm{MC}_{\mathrm{e}}}{\mathrm{MC}_{\mathrm{o}}-\mathrm{MC}_{\mathrm{e}}}$

Di mana : $M R=$ moisture ratio, $\mathrm{MC}_{\mathrm{t}}=$ kandungan air pada waktu $\mathrm{t}, \mathrm{MC}_{0}=$ kadar air awal, $\mathrm{MC}_{\mathrm{e}}=$ keseimbangan kadar air.

\section{Penurunan berat}

$P B=\frac{\left(M_{0}-M_{t}\right)}{M_{0}} \times 100$

$\mathrm{PB}=$ penurunan berat (\%), $\mathrm{M}_{0}=$ berat rumput laut awal, $\mathrm{M}_{\mathrm{t}}=$ berat rumput laut waktu $\mathrm{t}$ (menit)

\section{Laju pengeringan (LP)}

Laju pengeringan dihitung berdasarkan metode Torki-Herchagani, Ghasemi-Varnamkhasni, Ghanbarian, Sadeghi, \& Tohidi (2016) dengan persamaan sebagai berikut:

$L P=\frac{d M t}{d t}=\frac{M_{0}-M_{t}}{\Delta t}$

$\mathrm{LP}=$ laju pengeringan $\left(\mathrm{g} \cdot \mathrm{min}^{-1}\right), \mathrm{Mt}=$ berat sampel waktu t, Dt = selisih waktu (menit)

\section{Difusi efektif kadar air $\left(\boldsymbol{D}_{\text {eff }}\right)$}

Difusi efektif kadar air secara umum disepakati sebagai mekanisme utama pergerakan air menuju permukaan untuk proses evaporasi. Koefisien difusi dapat ditentukan dari slope plot normalisasi moisture ratio, In $(M R)$ per waktu, menggunakan persamaan sebagai berikut (Song et al, 2016):

$\ln (M R)=\ln \left(\frac{8}{\pi^{2}}\right)-\left(\frac{\pi^{2} D_{\text {eff }}}{4 L^{2}}\right)$

$D_{\text {eff }}=$ difusi efektif $\left(\mathrm{mm}^{2} /\right.$ detik),

$L=$ setengah ketebalan sampel $(\mathrm{mm})$

\section{Konsumsi energi spesifik (Specific energy consumption/SEC)}

Untuk mengevaluasi konsumsi energi proses pengeringan menggunakan oven gelombang mikro dilakukan dengan menghitung total output gelombang mikro per unit air yang diuapkan. Dihitung dengan persamaan Song et al. (2016):

$\mathrm{SEC}=\frac{\mathrm{Q}}{\Delta \mathrm{m}}$

$S E C=$ specific consumption energy $\left(\mathrm{J} / \mathrm{g} \cdot \mathrm{H}_{2} \mathrm{O}\right)$,

$\mathrm{Q}=$ total energi yang diserap gelombang mikro (Joule), $\mathrm{Dm}=$ jumlah total air yang diuapkan $(\mathrm{g})$.

$\mathrm{Q}=$ arus (ampere) $x$ tegangan (volt) $\times$ waktu (detik)... (6)

Di mana nilai arus dan tegangan diukur menggunakan tang meter.

\section{Efisiensi energi}

Efisiensi energi pengering gelombang mikro dihitung sebagai rasio energi yang dipakai untuk evaporasi air dalam bahan dengan energi yang dialirkan dari magnetron (Jafari, Kalantari, \& Azadbakht, 2018).

$\eta=\frac{Q_{\text {eva }}}{E_{\text {del }}}$

Di mana $\mathrm{h}=$ efisiensi energi $(\%), \mathrm{Q}_{\text {eva }}=$ energi yang dipakai untuk evaporasi $(\mathrm{kJ}), \mathrm{E}_{\mathrm{del}}=$ energi yang dialirkan dari magnetron $(\mathrm{kJ})$. Sedangkan energi yang dipakai untuk proses evaporasi rumput laut dihitung dengan persamaan berikut:

$Q_{\text {eva }}=h_{\text {fg }} W_{\text {eva }}$

$W_{\text {eva }}=$ jumlah air yang terevaporasi $(\mathrm{kg})$ dari rumput laut, $\mathrm{h}_{\mathrm{fg}}=$ panas latent air dalam jaringan rumput laut. Kemudian $\mathrm{h}_{\mathrm{fg}}$ ditentukan dengan rumus

$h_{\mathrm{fg}}=319351 \mathrm{MC}^{-1,446}$

\section{HASIL DAN PEMBAHASAN}

\section{Efek Level Daya terhadap Performa Pengeringan}

Performa pengeringan rumput laut menggunakan gelombang mikro dengan variasi perlakuan perbedaan level daya ditunjukkan pada Gambar 3. Suhu permukaan rumput laut meningkat drastis pada awal pengeringan hingga menit ke 10 , terjadi pada semua perlakuan. Pada akhir pengeringan suhu tertinggi diperoleh perlakuan level daya 600 watt yaitu $77,90 \pm 0,71$ ${ }^{\circ} \mathrm{C}$. Sedangkan level daya 500 dan 400 watt suhu yang dicapai adalah $72,00 \pm 4,11$ dan $69,55 \pm 2,20^{\circ} \mathrm{C}$. Kenaikan suhu menyebabkan penurunan berat rumput laut. Penurunan berat rumput laut semakin besar seiring 

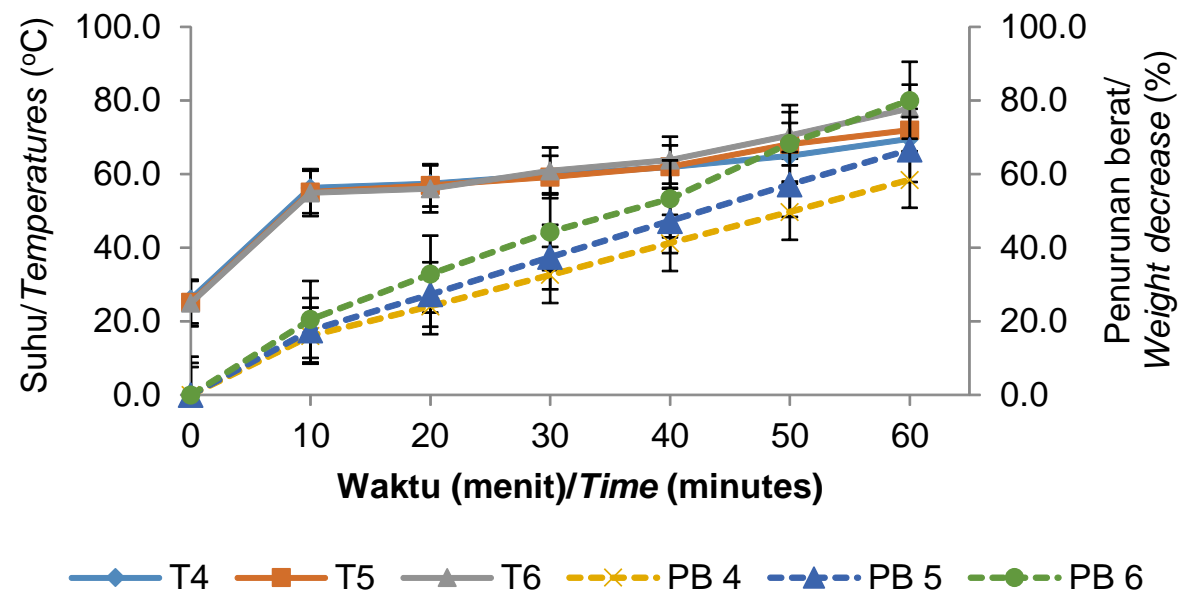

Keterangan/Notes :

$\mathrm{T} 4$ = Suhu pada level daya 400 watt/Temperature on power level 400 watt

PB4 = Penurunan berat pada level daya 400 watt/Weight decrease on power level 400 watt

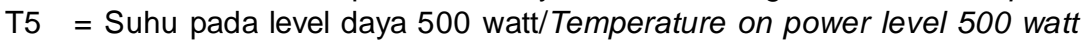

PB5 = Penurunan berat pada level 500 watt/Weight decrease on power level 500 watt

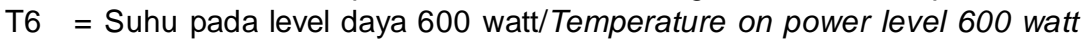

PB6 = Penurunan berat pada level 600 watt/Weight decrease on power level 600 watt

Gambar 3. Efek perbedaan level daya terhadap suhu dan berat rumput laut

Figure 3. Effect of different power level on temperatures and weight of seaweed

kenaikan suhu dan lama proses pengeringan. Pada level daya 600 watt presentase berat akhir terhadap berat awal sebesar 80,02 $\pm 0,84 \%$, diikuti oleh level daya 500 dan 400 watt berturut-turut sebesar $66,66 \pm 2,21 \%$ dan $58,43 \pm 0,26 \%$.
Rasio kadar air $(M R)$ rumput laut selama proses pengeringan ditampilkan pada Gambar 4. Nilai ini menggambarkan perbandingan kadar air rumput laut pada waktu tertentu dengan kadar air awal. Perlakuan level daya magnetron berpengaruh terhadap

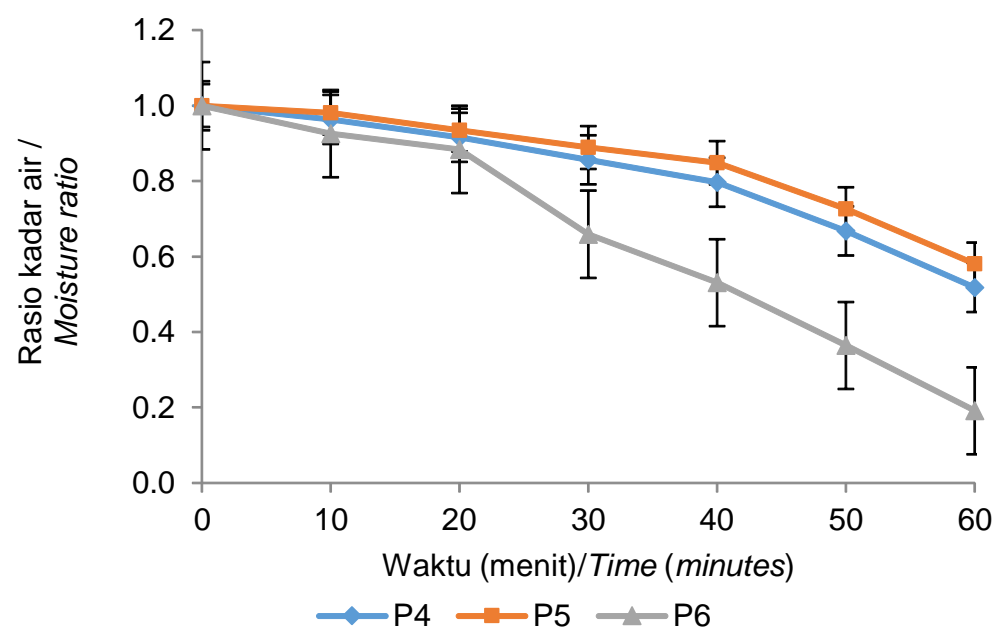

Keterangan/Notes:

P4 = Level daya 400 watt $/$ Power level 400 watt

P5 = Level daya 500 watt/Power level 500 watt

P6 = Level daya 600 watt $/$ Power level 600 watt

Gambar 4. Efek perbedaan level daya terhadap rasio kadar air

Figure 4. Effect of different power level on moisture ratio 
penurunan $M R$. Nilai $M R$ yang rendah menunjukkan terjadi penurunan kadar air yang besar pada sampel pengeringan. Level daya yang lebih tinggi menyebabkan $M R$ pada akhir periode pengeringan lebih tinggi. MR yang dihasilkan setelah pengeringan selama 60 menit ialah $0,19 \pm 0,06,0,58 \pm 0,03$ dan $0,52 \pm 0,04$ berturut-turut untuk P6, P5 dan P4.

Nilai laju pengeringan rumput laut menggunakan gelombang mikro bisa dilihat pada Gambar 5. Pada level daya 600 watt (P6) menghasilkan laju pengeringan paling tinggi di antara level daya lainnya (P5 \& P4). Rata-rata laju pengeringan sebesar
$9,88 \pm 2,40 \mathrm{~g} /$ menit untuk $\mathrm{P} 4,11,18 \pm 2,42 \mathrm{~g} /$ menit untuk P5 dan 13,15 $\pm 2,80 \mathrm{~g} /$ menit untuk P6. Pola laju pengeringan dari ketiga perlakuan hampir sama yaitu tinggi pada 10 menit pertama kemudian turun pada menit 20, dan stabil hingga akhir pengeringan.

Pergerakan air dalam inti bahan rumput laut menuju permukaan dinyatakan sebagai difusi efektif $\left(D_{\text {eff }}\right)$. Hal ini karena dalam pengeringan volumetric, bahan yang dipanaskan terlebih dahulu adalah bagian dalam, sehingga penting untuk mengetahui kecepatan pergerakan uap air menuju permukaan. $D_{\text {eff }}$ air dalam rumput laut selama pengeringan dengan level daya

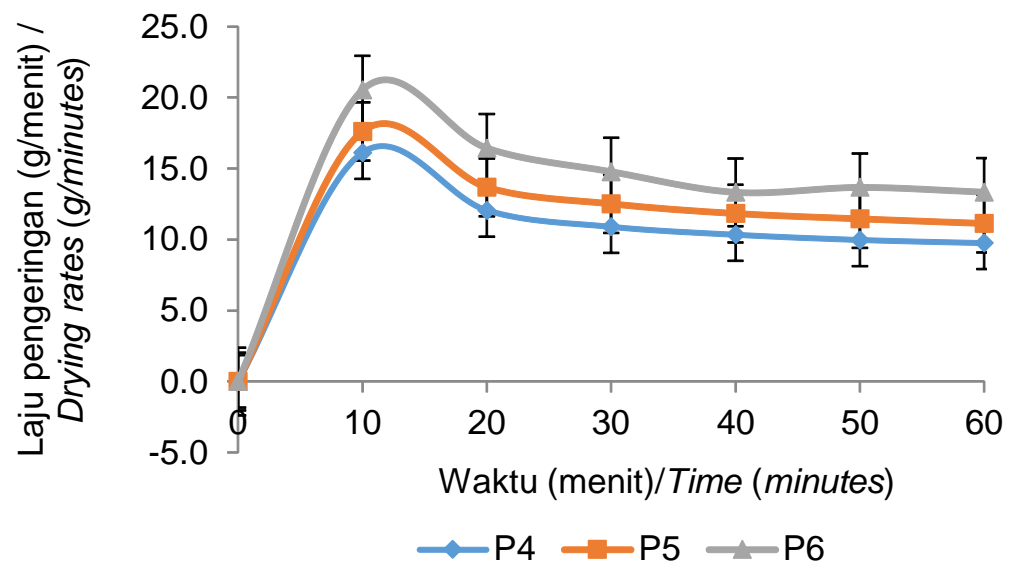

Keterangan/Notes :

P4 = Level daya 400 watt/Power level 400 watt

P5 = Level daya 500 watt/Power level 500 watt

P6 = Level daya 600 watt/Power level 600 watt

Gambar 5. Efek perbedaan level daya terhadap laju pengeringan

Figure 5. Effect of different power level on drying rates

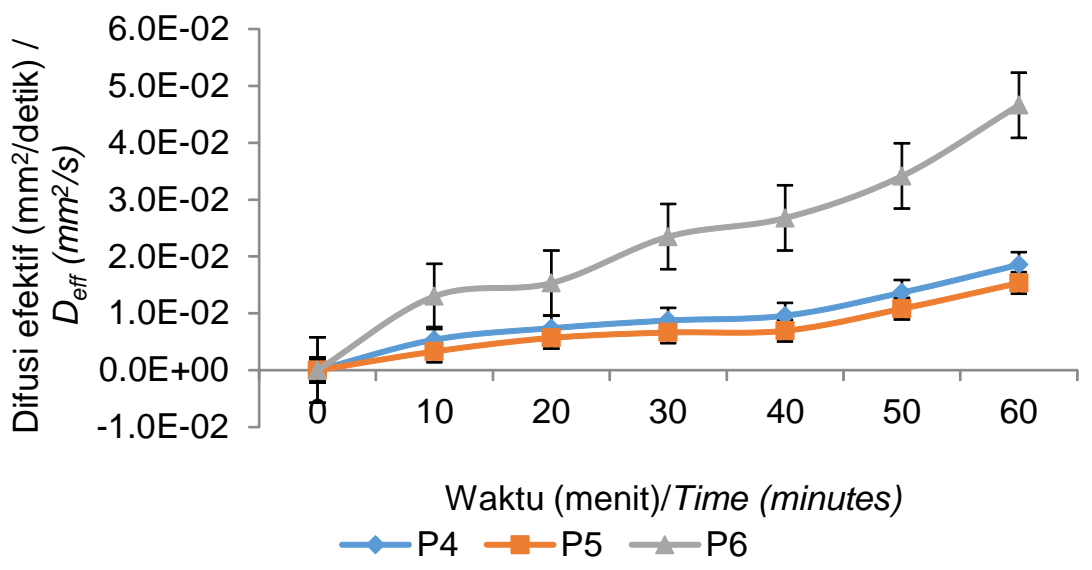

Keterangan/Notes:

P4 = Level daya 400 watt/Power level 400 watt

P5 = Level daya 500 watt/Power level 500 watt

P6 =Level daya 600 watt/Power level 600 watt

Gambar 6. Efek perbedaan level daya terhadap difusi efektif pengeringan

Figure 6. Effect of different power level on diffusion effective of drying 
yang berbeda bisa dilihat pada Gambar 6. Daya yang lebih tinggi (P6) menghasilkan pergerakan air ke permukaan menjadi lebih cepat dibandingkan P5 \& $\mathrm{P} 4$. Nilai rata-rata $D_{\text {eff }} \mathrm{P} 4$ ialah $9,04 \times 10^{-3} \pm 4,79 \times 10$ ${ }^{3} \mathrm{~mm}^{2} /$ detik, $6,95 \times 10^{-3} \pm 4,29 \times 10^{-3} \mathrm{~mm}^{2} /$ detik untuk P5 dan P6 sebesar 2,28 $\times 10^{-2} \pm 1,25 \times 10^{-2} \mathrm{~mm}^{2} /$ detik.

Specific energy consumption (SEC) dan efisiensi energi pengeringan rumput laut ditampilkan pada Gambar 7. SEC memberikan informasi kebutuhan energi (J) untuk menguapkan 1 gram air. Nilai $S E C$ yang diperoleh sebesar 4,38 $\pm 0,90-4,51 \pm 1,20 \mathrm{~J} / \mathrm{g} \mathrm{H}_{2} \mathrm{O}$. Level daya yang berbeda pada proses pengeringan tidak menyebabkan nilai SEC yang dihasilkan berbeda nyata. Selanjutnya pada Gambar 7 juga ditunjukkan efisiensi proses pengeringan. Effisiensi tertinggi pada perlakuan level daya 600 watt yaitu sebesar $23,42 \pm 3,10 \%$, tidak berbeda nyata dengan perlakuan lainnya (P5 \& P4) yang memiliki efisiensi $22,89 \pm 2,20$ $\%$ dan $22,56 \pm 2,60 \%$.

Level daya yang berbeda memberi masukan energi yang berbeda ke magnetron, semakin besar daya yang digunakan, magnetron memperoleh energi yang lebih besar. Magnetron dengan energi yang lebih besar menghasilkan gelombang elektromagnetik dengan intensitas lebih tinggi. Gelombang ini memicu gesekan antar molekul dalam rumput laut terutama air karena air merupakan unsur dominan. Gesekan tersebut menyebabkan suhu dalam sel rumput laut meningkat dan menyebabkan air menguap.

Suhu permukaan rumput laut yang dicapai tidak berbeda signifikan antar perlakuan karena sumber panas yang diproduksi berasal dari bagian dalam rumput laut sehingga kemungkinan terjadi perubahan/ penurunan suhu saat panas mencapai permukaan. Namun demikan efek yang ditimbulkan oleh perbedaan level daya, bisa dilihat dari penurunan berat rumput laut. Presentase penurunan berat antar perlakuan berbeda secara signifikan $(P<0,05)$. Berat rumput laut berkurang akibat menguapnya kandungan air di dalamnya hal ini disebabkan karena adanya kenaikan suhu. Menurut Song et al. (2016), mekanisme pengeringan menggunakan gelombang mikro berbeda dengan pengeringan konvensional (konduksi dan konveksi), suhu pada bagian dalam bahan mengalami kenaikan suhu lebih tinggi dibandingkan bagian permukaan. Level daya yang tinggi menyebabkan radiasi gelombang elektromagnetik akan semakin banyak diserap bahan.

Rasio kadar air turun dengan bertambahnya waktu proses pengeringan dan akibat kenaikan level daya magnetron. Kondisi ini terjadi karena adanya perbedaan tekanan uap air antara bagian dalam dan permukaan rumput laut sehingga menyebabkan terjadinya difusi uap air yang lebih banyak dan lebih

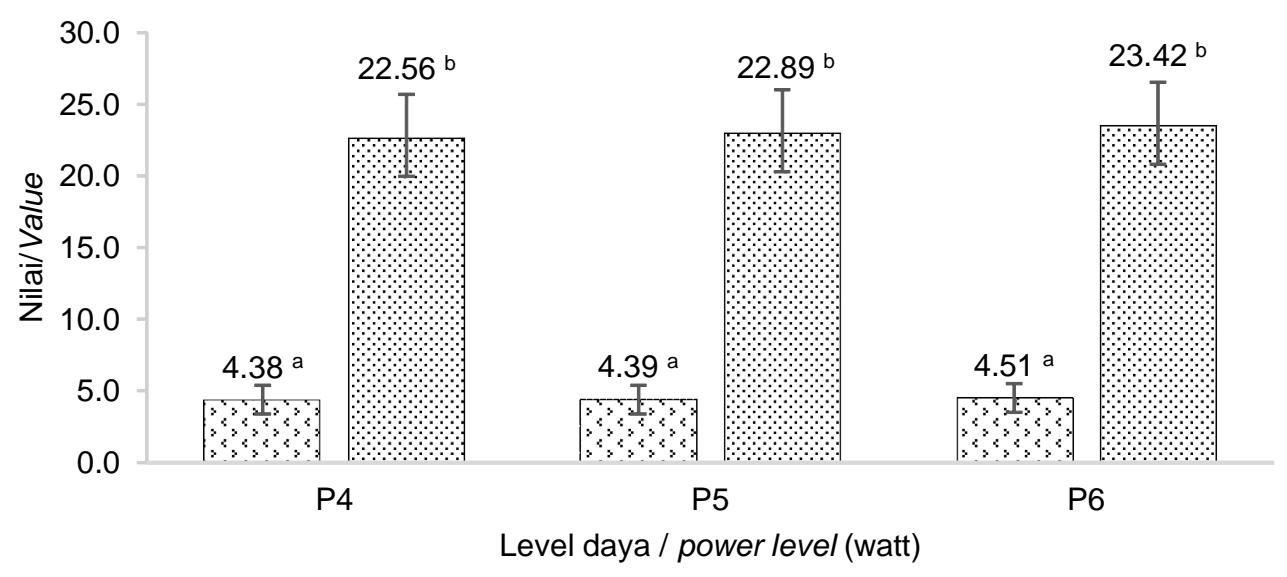

[. Konsumsi energi spesifik/Specific energy consumption $\left(\mathrm{J} / \mathrm{g} \mathrm{H}_{2} \mathrm{O}\right)$

Efisiensi Energi/Energy efficiency (\%)

Keterangan/notes

P4 = Level daya 400 watt/Power level 400 watt

P5 = Level daya 500 watt $/$ Power level 500 watt

P6 = Level daya 600 watt $/$ Power level 600 watt

Gambar 7. SEC dan efisiensi energi pengeringan rumput dengan level daya berbeda

Figure 7. SEC and energy efficiency of drying seaweed with different power levels 
cepat. Hasil serupa dikemukakan oleh Horuz, Bozkurt, Karatas dan Maskan (2018); Horuz, Bozkurt, Karatas dan Maskan (2017); Torki, Ghasemi, Ghanbarian, Sadeghi, dan Tohidi. (2016).

Level daya 600 watt (P6) menghasilkan laju pengeringan paling tinggi. Tingginya laju pengeringan ini disebabkan karena gesekan antar molekul air terjadi pada P6 lebih banyak sehingga menyebabkan uap air yang dikeluarkan dari rumput laut lebih banyak pula. Intensitas gesekan antar molekul air yang banyak tersebut disebabkan tingginya gelombang elektromagnetik yang dipancarkan oleh magnetron. Puncak laju pengeringan terjadi pada menit ke-10 kemudian turun hingga menit ke-60. Hal mengindikasikan bahwa kadar air dalam bahan di menit ke-10 sangat tinggi sehingga absorpsi gelombang elektromagnetik juga tinggi, kemudian karena kadar air semakin turun maka laju pengeringanpun menjadi turun akibat absorbsi gelombang elektromagnetik yang berkurang. Menurut Demiray, Seker dan Tulek (2017), kadar air dalam bahan sangat tinggi pada awal pengeringan yang menyebabkan penyerapan energi gelombang elektromagnetik lebih tinggi sehingga laju pengeringan naik, dan akan turun saat kadar air bahan berkurang.

$D_{\text {eff }}$ tertinggi pada perlakuan P6. Level daya yang lebih tinggi menghasilkan pergerakan air dari dalam bahan ke permukaan menjadi lebih cepat. Pada penelitian Zhao et al. (2019); Song et al. (2016); Darvishi, Azadbakht, Rezaeiasl, dan Farhang (2013). $D_{\text {eff }}$ bahan yang dikeringkan menjadi lebih tinggi ketika daya magnetron yang digunakan lebih besar karena energi gelombang mikro yang diserap lebih besar. Berdasarkan persamaan $4, D_{\text {eff }}$ merupakan fungsi dari $M R$ dan waktu $(t)$. MR yang rendah menghasilkan $D_{\text {eft }}$ yang tinggi. Begitu juga terhadap fungsi $t, D_{\text {eff }}$ akan naik sering dengan bertambahnya nilai $t$.

Mengacu pada persamaan 5 , konsumsi energi spesifik (SEC) pada proses pengeringan menggunakan energi gelombang mikro ditentukan oleh daya magnetron yang digunakan serta kandungan air dalam bahan yang dikeringkan (Soysal, Arslan, \& Keskin, 2009). Peningkatan level daya tidak memberikan pengaruh signifikan terhadap perubahan SEC. Pada saat daya yang digunakan besar, dihasilkan penguapan air bahan yang besar pula sehingga SEC relatif tidak berbeda antar perlakuan. Menurut Song et al. (2016); Darvishi et al. (2013) nilai SEC bisa tidak berubah atau bahkan turun saat daya gelombang mikro yang digunakan lebih tinggi, hal ini disebabkan peningkatan daya lebih kecil dibandingkan laju pengeringan.

Efisiensi energi pengeringan dipengaruhi oleh besaran konsumsi energi. Oleh karena itu kenaikan level daya tidak berpengaruh terhadap nilai efisiensi energi. Menurut Shihonga et al. (2019). Efisiensi memiliki tren naik saat energi yang digunakan dinaikkan. Saat energi tinggi maka air yang diuapkan meningkat signifikan.

\section{Efek Ketebalan terhadap Performa Pengeringan}

Mempertimbangkan hasil pada perlakuan level daya yang menunjukkan bahwa level daya 600 watt (P6) menghasilkan penurunan berat, laju pengeringan, difusi efektif dan efisiensi tertinggi maka perlakukan berikutnya menggunakan level daya magnetron 600 watt. Perlakuan perbedaan ketebalan rumput laut yang dikeringkan menggunakan gelombang mikro dan pengaruhnya terhadap perubahan suhu permukaan dan presentase berat rumput laut ditampilkan pada Gambar 8. Rata-rata suhu awal permukaan rumput laut ialah $24,12 \pm 0,91^{\circ} \mathrm{C}$ dan suhu akhir setelah pengeringan selama 30 menit bervariasi antara $70,20-80,10^{\circ} \mathrm{C}$. Suhu tertinggi dicapai oleh perlakuan ketebalan $7 \mathrm{~cm}$ (M7) yaitu $80,10 \pm 6,13^{\circ} \mathrm{C}$, sedangkan terendah pada perlakuan ketebalan $3 \mathrm{~cm}(\mathrm{M} 3)$ yaitu $70,20 \pm 1,15^{\circ} \mathrm{C}$. Data ini menunjukkan bahwa rumput laut yang lebih tebal akan menghasilkan suhu permukaan yang lebih tinggi. Berbeda dengan parameter presentase penurunan berat rumput laut, pada parameter ini, ketebalan $3 \mathrm{~cm}$ menghasilkan penurunan berat paling tinggi yaitu $87,92 \pm 0,30 \%$. Sedangkan penurunan terendah pada perlakuan ketebalan $7 \mathrm{~cm}$ yaitu $73,00 \pm 0,30 \%$. Rumput laut yang lebih tipis saat dikeringkan mengalami penurunan berat lebih tinggi dibandingkan rumput laut yang lebih tebal.

Lapisan rumput laut yang lebih tebal menyerap gelombang mikro lebih besar dibandingkan lapisan yang tipis. Akibatnya suhu rumput laut pada M7 lebih tinggi dibandingkan suhu pada M5 \& M3. Penelitian Jafari et al. (2018), menyebutkan bahwa padi yang dikeringkan menggunakan pengering gelombang mikro dengan ketebalan $18 \mathrm{~mm}$ menyerap gelombang mikro lebih besar dibandingkan padi dengan ketebalan $6 \mathrm{~mm}$. Pada bahan yang lebih tebal, gelombang mikro akan diserap secara optimal, sedangkan pada bahan yang tipis tidak semua gelombang mikro terserap bahan namun sebagian akan dipantulkan ke dinding cavity.

Pada parameter penurunan berat, terjadi pola yang berbeda. Rumput laut dengan ketebalan $3 \mathrm{~cm}$ (M3) mengalami penurunan berat paling besar dan M7 paling kecil. Penyebabnya ialah uap air yang keluar dari dalam rumput laut lebih cepat mencapai permukaan sehingga berat turun lebih banyak.

Nilai rasio kadar air $(M R)$ akibat perbedaan ketebalan rumput laut ditampilkan pada Gambar 9. $M R$ yang rendah menunjukkan telah terjadi penguapan air yang tinggi dari rumput laut. Berdasarkan data yang diperoleh, MR terendah pada perlakuan M3 $(0,05 \pm 0,01)$ 


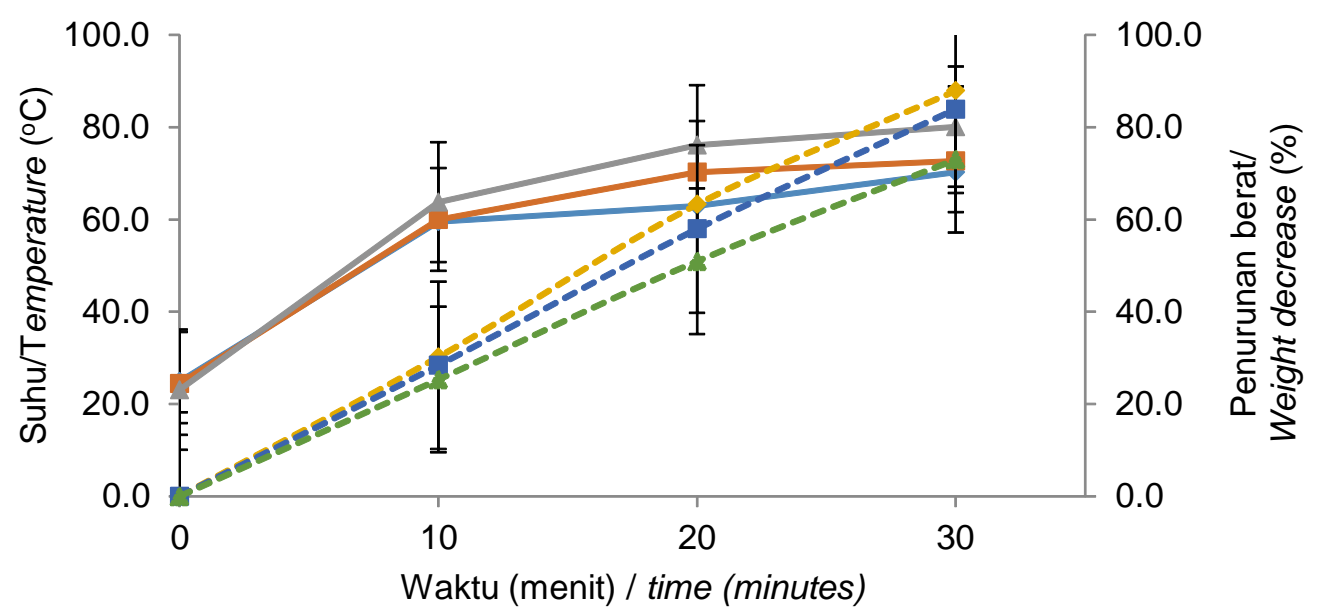

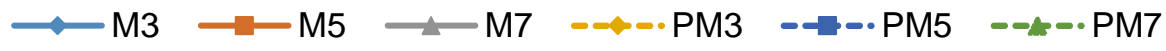

Keterangan/Notes

M3 = Ketebalan $3 \mathrm{~cm} /$ Thickness $3 \mathrm{~cm}$

M5 = Ketebalan $5 \mathrm{~cm} /$ Thickness $5 \mathrm{~cm}$

$\mathrm{M} 7=$ Ketebalan $7 \mathrm{~cm} /$ Thickness $7 \mathrm{~cm}$

PM3 = Penurunan berat pada ketebalan $3 \mathrm{~cm} /$ Weight decrease at $3 \mathrm{~cm}$ thickness

PM5 = Penurunan berat pada ketebalan $5 \mathrm{~cm} /$ Weight decrease at $5 \mathrm{~cm}$ thickness

$\mathrm{PM} 7$ = Penurunan berat pada ketebalan $7 \mathrm{~cm} /$ Weight decrease at $7 \mathrm{~cm}$ thickness

Gambar 8. Efek perbedaan ketebalan terhadap suhu dan penurunan berat / Figure 8. Effect of different thickness on temperature and weight decrease

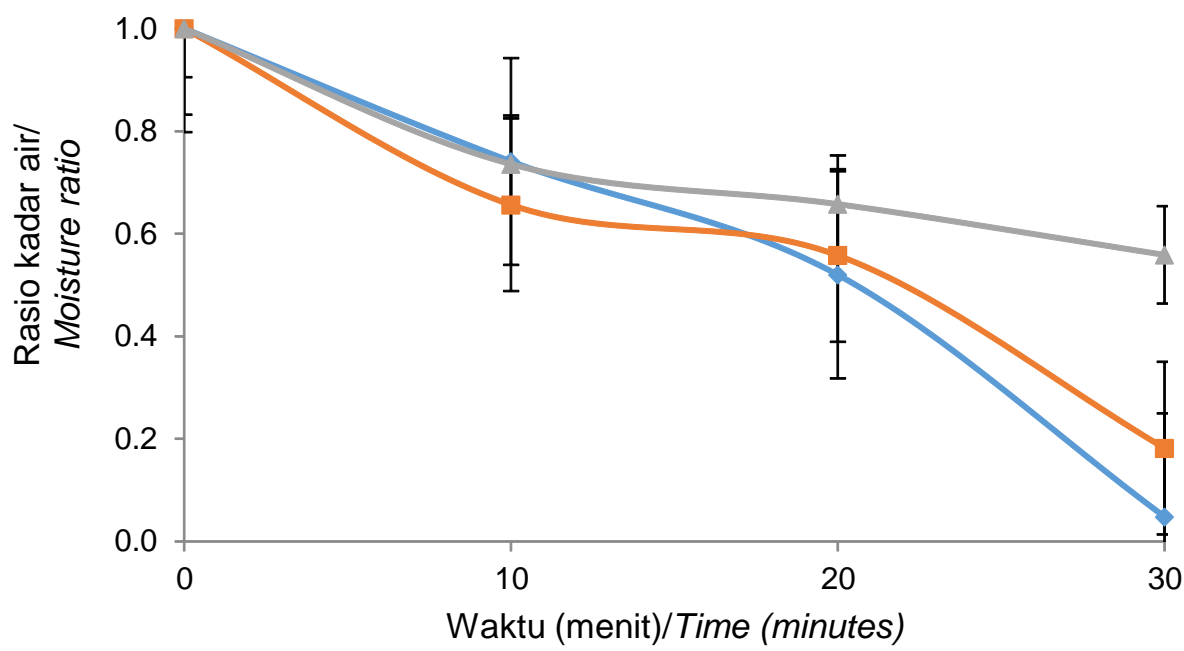

Keterangan/Notes

M3 = Ketebalan $3 \mathrm{~cm} /$ Thickness $3 \mathrm{~cm}$

M5 = Ketebalan $5 \mathrm{~cm} /$ Thickness $5 \mathrm{~cm}$

M7 = Ketebalan $7 \mathrm{~cm} /$ Thickness $7 \mathrm{~cm}$

Gambar 9. Efek perbedaan ketebalan terhadap rasio kadar air

Figure 9. Effect of different thickness on moisture ratio 
dan $M R$ tertinggi pada perlakuan $\mathrm{M7}(0,56 \pm 0,08)$. Nilai $M R$ yang dihasilkan berbanding lurus dengan ketebalan rumput laut yang dikeringkan. Semakin tipis rumput laut maka $M R$ akan semakin rendah, karena air dalam bahan lebih mudah menguap. Quertani et al (2018); Jiang, Dang, Tan, Pan, dan Wei (2017) mengemukakan, dalam pengeringan menggunakan gelombang mikro, uap air yang dihasilkan gelombang elektromagnetik akan mudah melewati permukaan bila bahan yang dikeringkan memiliki ketebalan lebih kecil sehingga proses evaporasi berjalan cepat.

Laju pengeringan rumput laut selama pengeringan ditunjukkan pada Gambar 10. Laju pengeringan paling tinggi terjadi pada menit ke 10 yang mencapai 8,87$10,58 \mathrm{~g} /$ menit kemudian turun pada menit berikutnya. Pada menit ke 30 laju pengeringan hanya mencapai 2,58-3,03 g/menit. Pada menit ke-10 kadar air dalam rumput laut masih tinggi sehingga gelombang elektromagnetik terserap maksimal menghasilkan penguapan kadar air yang tinggi.

Nilai rata-rata laju pengeringan tertinggi dihasilkan pada perlakuan $M 3$ yaitu $6,42 \pm 3,89 \mathrm{~g} / \mathrm{menit}$, dan terendah pada perlakuan M7 yaitu 5,31 $\pm 3,22 \mathrm{~g} /$ menit. Perbedaan ketebalan berpengaruh terhadap laju pengeringan, pada ketebalan $3 \mathrm{~cm}$ proses difusi uap air ke permukaan berjumlah lebih banyak.
Hasil perhitungan parameter difusi efektif $\left(D_{\text {eff }}\right)$ dalam ketebalan yang berbeda bisa dilihat pada Gambar 11. $D_{\text {eff }}$ tertinggi pada menit ke 30 dengan nilai $0,17 \pm 0,01 \mathrm{~mm}^{2} /$ detik (M3), $0,10 \pm 0,03 \mathrm{~mm}^{2} /$ detik (M5) dan 0,03 $\pm 0,008 \mathrm{~mm}^{2} /$ detik (M7). Sedangkan nilai rata-rata selama proses pengeringan ialah $0,09 \pm 0,06$ $\mathrm{mm}^{2} /$ detik untuk M3, 0,07 $\pm 0,02 \mathrm{~mm}^{2} /$ detik untuk M5 dan $0,04 \pm 0,01 \mathrm{~mm}^{2} /$ detik untuk M7. Pada saat rumput laut memiliki ketebalan rendah akan menyebabkan pergerakan uap air menuju permukaan lebih cepat. Fenomena ini juga disampaikan oleh Jiang et al. (2017) dan Fu, Chen, Huang, dan Luo (2017).

Berikutnya adalah hasil analisa efisiensi energi dan SEC pada pengeringan rumput laut dalam kondisi ketebalan yang berbeda. Rata-rata hasil analisa ditunjukkan pada Gambar 12. Kebutuhan energi pada perlakuan $\mathrm{M} 3$ sebesar 2,96 $\pm 0,24 \mathrm{~J} / \mathrm{g} \mathrm{H}_{2} \mathrm{O}$ yang merupakan SEC terendah dibandingkan perlakuan lainnya yaitu M5: 3,34 $\pm 0,14 \mathrm{~J} / \mathrm{g} \mathrm{H}_{2} \mathrm{O}$ dan $\mathrm{M} 7: 4,75 \pm$ $0,24 \mathrm{~J} / \mathrm{g} \mathrm{H}_{2} \mathrm{O}$. Dalam hal ini SECdipengaruhi oleh tingkat ketebalan, semakin tinggi ketebalan akan dibutuhkan energi yang semakin tinggi untuk menguapkan air dalam rumput laut. Nilai ketebalan bahan berpengaruh terhadap kebutuhan energi gelombang mikro untuk penguapan air, ketebalan bahan yang lebih kecil kebutuhan energinya lebih rendah (Azimi \& Hoseini, 2019).

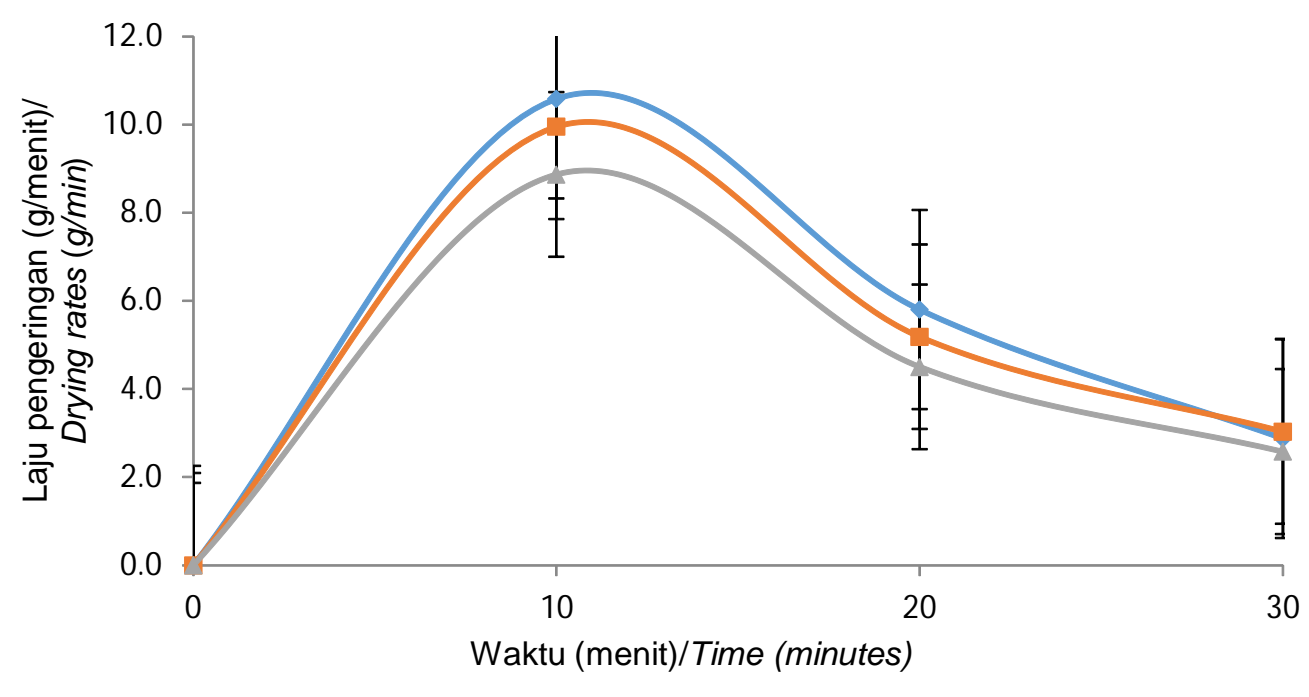

Keterangan/Notes

M3 = Ketebalan $3 \mathrm{~cm} /$ Thickness $3 \mathrm{~cm}$

M5 = Ketebalan $5 \mathrm{~cm} /$ Thickness $5 \mathrm{~cm}$

M7 = Ketebalan $7 \mathrm{~cm} /$ Thickness $7 \mathrm{~cm}$

Gambar 10. Efek perbedaan ketebalan terhadap laju pengeringan

Figure 10. Effect of different thickness on drying rates 


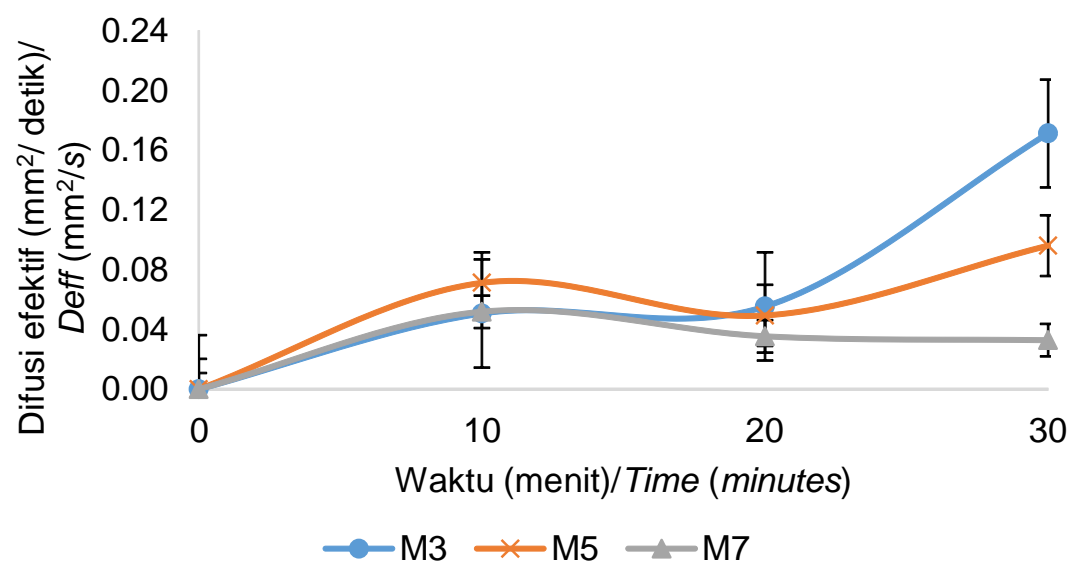

Keterangan/Notes

M3 = Ketebalan $3 \mathrm{~cm} /$ Thickness $3 \mathrm{~cm}$

M5 = Ketebalan $5 \mathrm{~cm} /$ Thickness $5 \mathrm{~cm}$

M7 = Ketebalan $7 \mathrm{~cm} /$ Thickness $7 \mathrm{~cm}$

Gambar 11. Efek perbedaan ketebalan terhadap difusi efektif pengeringan /

Figure 11. Effect of different thickness on effective diffusion

Nilai efisiensi berbanding terbalik dengan Nilai SEC (Bermudez, Beneroso, Rey-Raap, Arenillas, \& Menéndez, 2015). Efisiensi energi yang dihasilkan sebesar 17,87-22,93\%. Efisiensi tertinggi pada perlakuan M5, tetapi nilai ini tidak berbeda nyata dengan perlakuan M3. Sedangkan efisiensi terendah pada perlakuan M7. Data ini menginformasikan bahwa ketebalan berpengaruh terhadap efisiensi energi pengeringan, semakin besar ketebalan rumput laut maka efisiensi akan semakin rendah.

Kualitas rumput laut hasil pengeringan tidak dibahas dalam penelitian ini namun beberapa penelitian

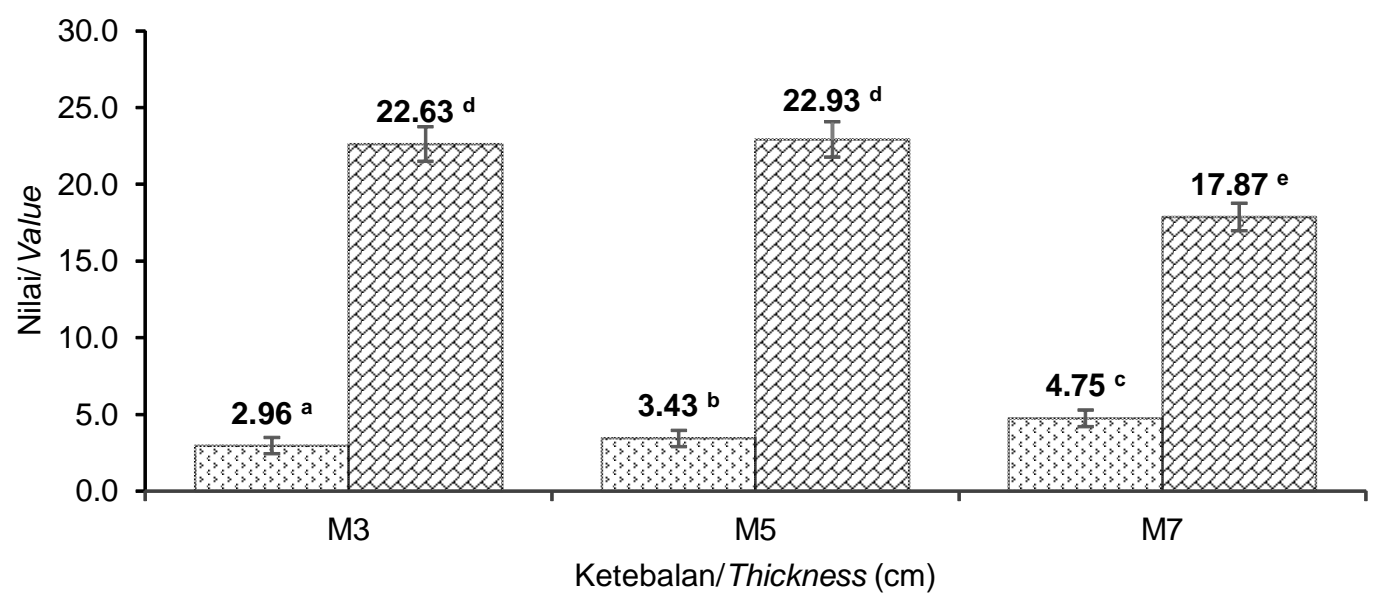

Konsumsi energi spesifik/Specific energy consumption $\left(\mathrm{J} / \mathrm{g} \mathrm{H}_{2} \mathrm{O}\right)$

๑ Efisiensi Energi/Energy efficiency (\%)

Keterangan/Notes :

M3 = Ketebalan $3 \mathrm{~cm} /$ Thickness $3 \mathrm{~cm}$

M5 $=$ Ketebalan $5 \mathrm{~cm} /$ Thickness $5 \mathrm{~cm}$

M7 = Ketebalan $7 \mathrm{~cm} /$ Thickness $7 \mathrm{~cm}$

Gambar 12. SEC dan Efisiensi energi pengeringan rumput laut dengan ketebalan berbeda

Figure 12. SEC and energy efficiency of drying seaweed with different thickness 
menyebutkan bahwa pengeringan menggunakan energi gelombang mikro tidak berpengaruh pada sifat fungsional produk turunan rumput laut seperti karaginan. Serowik et al. (2018) menyimpulkan bahwa pengeringan karaginan menggunakan energi gelombang mikro tidak merubah spektra gugus fungsional yang terkandung. Hal senada disampaikan oleh Wahyu et al. (2019) bahwa kekuatan gel dan kadar sulfat karaginan dari rumput laut Eucheuma cottonii hasil pengeringan dalam gelombang mikro tidak menunjukkan penurunan nilai dibandingkan rumput laut hasil pengeringan dengan sinar matahari.

\section{KESIMPULAN}

Performa pengeringan rumput laut menggunakan energi gelombang mikro telah diobservasi melalui parameter rasio kadar air $(M R)$, laju pengeringan dan difusi efektif. Peningkatan level daya (400-600 watt) berpengaruh terhadap parameter tersebut, level daya 600 watt menghasilkan $M R$ terendah $(0,19)$, laju pengeringan tertinggi $\left(13,15 \mathrm{~g} /\right.$ menit) dan $D_{\text {eff }}$ tertinggi $\left(2,28 \times 10^{-2} \mathrm{~mm}^{2} /\right.$ detik). Rumput laut dengan ketebalan $3 \mathrm{~cm}$ memperoleh $M R$ terendah $(0,05)$, laju pengeringan tertinggi $(6,42 \mathrm{~g} / \mathrm{menit})$ dan $D_{\text {eff }}$ tertinggi $\left(9,42 \times 10^{-2}\right.$ $\mathrm{mm}^{2} /$ detik).

Analisa konsumsi energi pengeringan meliputi parameter specific energy consumption (SEC) dan efisiensi energi. SEC pengeringan sebesar 4,38-4,51 $\mathrm{J} / \mathrm{g} \mathrm{H}_{2} \mathrm{O}$ dan efisiensi energi 22,56-23,42\% untuk level daya 400-600 watt. Perbedaan level daya tidak memberikan pengaruh signifikan terhadap kedua parameter tersebut. Sedangkan variasi ketebalan rumput laut antara $3 \mathrm{~cm}$ dan $7 \mathrm{~cm}$ memberi perbedaan hasil yang signifikan. Rumput laut $3 \mathrm{~cm}$ menghasilkan SEC terendah yaitu $2,96 \mathrm{~J} / \mathrm{g} \mathrm{H}_{2} \mathrm{O}$, dan efisiensi tertinggi pada ketebalan $5 \mathrm{~cm}$ yaitu 22,93\%. Rumput laut yang lebih tipis menghasilkan nilai kedua parameter tersebut lebih baik.

Mempertimbangkan uraian di atas, pengeringan rumput laut menggunakan energi gelombang mikro dengan level daya 600 watt dan ketebalan $3 \mathrm{~cm}$ menghasilkan performa dan konsumsi energi yang lebih baik.

\section{DAFTAR PUSTAKA}

Azimi, N. H., \& Hoseini, S. S. (2019). Study the effect of microwave power and slices thickness on drying characteristics of potato. Heat and Mass Transfer, 55, 2921-2930. doi: org/10.1007/s00231-019-02633-x

Bermudez, J. M., Beneroso, D., Rey-Raap, N., Arenillas, A., \& Menéndez, J. A. (2015). Energy consumption estimation in the scaling-up of microwave heating processes. Chemical Engineering and Processing, 95, 1-8. doi: org/10.1016/j.cep.2015.05.001
Darvishi, H., Azadbakht, M., Rezaeiasl, A., \& Farhang, A. (2013). Drying characteristics of sardine fish dried with microwave heating. Journal of the Saudi Society of Agricultural Sciences, 12, 121-127. doi: org/ 10.1016/j.jssas.2012.09.002

Demiray, E., Seker, A., \& Tulek, Y. (2017). Drying kinetics of onion (Allium cepa L.) slices with convective and microwave drying. Heat Mass Transfer, 53, 1817-1827. doi : 10.1007/s00231-016-1943-x

Fu, B. A., Chen, M. Q., Huang, Y. W., \& Luo, H. F. (2017). Combined effects of additives and power levels on microwave drying performance of lignite thin layer. Drying Technology, 35(2), 227-239. https://doi.org/ 10.1080/07373937.2016.1170029

Fu, B. A., Chen, M. Q., \& Song, J. J. (2017). Investigation on the microwave drying kinetics and pumping phenomenon of lignite spheres. Applied Thermal Engineering, 124, 371-380. doi : org/10.1016/ j.applthermaleng.2017.06.034

Fudholi, A., Sopian, K., Othman, M. Y., Ruslan, M. H. (2014). Energy and exergy analyses of solar drying system of red seaweed. Energy and Buildings, 68, 121-129.

Horuz, E., Bozkurt, H., Karatas, H., \& Maskan, M. (2018). Simultaneous application of microwave energy and hot air to whole drying process of apple slices: drying kinetics, modeling, temperature profile and energy aspect. Heat Mass Transfer, 54, 425-436. doi: 10.1007/ s00231-017-2152-y

Horuz, E., Bozkurt, B., Karatas, H., \& Maskan, M. (2017). Drying kinetics of apricot halves in a microwave-hot air hybrid oven. Heat Mass Transfer, 53, 2117-2127. doi.org/ 10.1007/s00231-017-1973-z

Jafari, H., Kalantari, D., \& Azadbakht. (2018). Energy consumption and qualitative evaluation of a continuous band microwave dryer for rice paddy drying. Energy, 142, 647-654. doi : org/10.1016/j.energy.2017.10.065

Jiang, J., Dang, L., Tan, H., Pan, B., \& Wei, H. (2017). Thin layer drying kinetics of pre-gelatinized starch under microwave. Journal of the Taiwan Institute of Chemical Engineers, 72, 10-18. doi.org/10.1016/ j.jtice.2017.01.005

Kementerian Kelautan dan Perikanan (KKP) (2018). Laporan Kinerja TA 2017. Kementerian Kelautan dan Perikanan Republik Indonesia.

Manikantun, M. R., Barnwarl, P., \& Goyal, R. K. (2014). Modelling the drying kinetics of paddy in an integrated paddy dryer. Journal of Food Science and Technology, 51, 4-9. doi: org/10.1007/s13197-013-1250-1

Metaxas, A. C and Meredith, R. J. (2008). Industrial Microwave Heating. The Institution of Engineering and Technology: London, UK, Volume 4.

Quertani, S., Koubaa, A., Azzouz, S., Bahar, R., Hassini, L., \& Belghith. (2018). Microwave drying kinetics of jack pine wood: determination of phytosanitary efficacy, energy consumption, and mechanical properties. European Journal of Wood and Wood Products, 76, 1101-1111. doi.org/10.1007/s00107018-1316-x

Serowik, M., Figiel, A., Nejman, M., Pudlo, A., Chorazyk, D., Kopec, W., Krokosz, D., Rychlicka-Rybska, J. 
(2018). Drying characteristics and properties of microwave - assisted spouted bed dried semirefined carrageenan. Journal of Food Engineering, 221, 2028. doi.org/10.1016/j.jfoodeng.2017.09.023

Shihong, T., Ravindra, A. V., Shaohua, J., Jinhui, P., Lihua, Z., lei, G., \& Xiao ling, L. (2020). Flash evaporation intensified by microwave energy and performance analysis. Applied Thermal Engineering, 165. https:// doi.org/10.1016/j. applthermaleng.2019.114471

Song, Z., Jing, C., Yao, L., Zhao, X., Wang, W., Mao., Y., \& Ma, C. (2016). Microwave drying performance of single-particle coal slime and energy consumption analyses. Fuel Processing Technology, 143, 69-78. doi.org/10.1016/j.fuproc.2015.11.012

Soysal, Y., Arslan, M., \& Keskin, M. (2009). Intermittent microwave convective air drying of oregano. Food Science Technology International, 15, 397-406.

Suherman, S., Djaeni, M., Kumoro, A.C., Prabowo, R.A., Rahayu, S., \& Khasanah, S. (2018). Comparison
Drying Behavior of Seaweed in Solar, Sun and Oven Tray Dryers. MATEC Web of Conferences, 156, 05007. doi.org/10.1051/matecconf/201815605007

Torki, H. M., Ghasemi, V. M., Ghanbarian, D., Sadeghi, M., \& Tohidi, M. (2016). Dehydration chracteristics and mathematical modelling lemon slices drying undergoing oven treatment. Heat Mass Transfer. 52, 281-289.

Wahyu, T. H., Prasetyo, A. W., \& Hakim, A. R. (2019). Pengeringan Rumput Laut Menggunakan Energi Gelombang Mikro dan Kualitas yang Dihasilkan. Prosiding Seminar Nasional Tahunan XVI Hasil Penelitian Perikanan dan Kelautan. Universitas Gadjah Mada. 379 - 384.

Zhao, P., Liu, C., Qu, W., He, Z., Gao, J., Jia, L., ... Ruan, R. (2019). Effect of temperature and microwave power levels on microwave drying kinetics of zhaotong lignite. Processes, 7(2). https://doi.org/10.3390/ pr7020074 